\title{
The Translation of English Passive Voice into Indonesian
}

\author{
Herlina Lindaria Simanjuntak \\ herlinalindaria12@gmail.com \\ Universitas Indraprasta PGRI
}

\begin{abstract}
English and Indonesian have different grammatical patterns and cultural values. That is why, many problems that students studying translation subject have to face. One of them is how to translate English Passive Voice into Indonesian. That is the reason the writer aims to do the research. The research is to describe the translation of English passive voice into Indonesian by analyzing two novels, which are Kristan Higgins' Waiting on You and its translation Nina Andiana's Penantian Terpanjang. This research uses qualitative method. The writer collected, identified, the data concerning with the translation of English passive voice. The results of the research shows that there are two categories of translating English passive voice into Indonesian, namely English passive voice can be translated both into Indonesian passive voice and English passive voice can be translated into Indonesian active voice. English passive voice is translated into Indonesian passive voice by using prefixes $d i$ and ter-, meanwhile English passive voice is translated into Indonesian active voice by using prefixes me-, men-, and ber-. From forty one data which are identified there are 32 data (78.04\%) of English passive voices translated into Indonesian passive voices and 9 data $(21.96 \%)$ of English passive voices translated into Indonesian active voices.
\end{abstract}

Keywords: Indonesian, passive voice, translation

\section{Introduction}

In this global and high technology era, people all over the world use English as an international language. A lot of information, knowledge, books, and magazines are written in English. Many use English as the first language in their lives, not only at their offices but also for their daily activities. That is why, language competence, especially in English is very important in this era. Therefore, many will encounter some difficulties if they do not understand English well. As the most dominant part of various languages in the world, English has been compared with many other languages, including Indonesian. Meanwhile English and Indonesian have different grammatical patterns and cultural values. Indonesian utterance is different from English utterance.

Every language has a unique and different characteristic that is why it is not easy to translate from English into Indonesian, and vice versa. Therefore, those who want to be a translator or to study translation will face some difficulties to improve their ability and skill. That is why, many problems that students studying translation subject have to face. One of them is how to translate "English Passive Voice into Indonesian". In this research, the writer tries to describe the translation of "English Passive Voice into Indonesian. The writer chooses "The Translation of English Passive voice into Indonesian" because from the writer own experience when teaching translation subject at one of the local university, I find out that most students have many difficulties to translate English passive voice into Indonesian. The examples of their difficulties are: Should English passive voice be translated into Indonesian passive voice in the same form of Indonesian passive voice or vice versa? Can English passive voice be translated into Indonesian by using affixes di-? Can English passive voice be translated into Indonesian by using affixes ter-? Can English passive voice be 
translated into Indonesian by using affixes ke-an? It means that the English passive voice can be translated into many words in Indonesian. It depends on the context. As stated by Larson (1984) "Translation is basically a change of form. When we speak of the form of a language, we are referring to the actual words, phrases, clauses, sentences, paragraphs etc., which are spoken or written." It means that we can change the form of a text or text from one language (source language) to another language (target language), but we must keep the meaning that is intended by the author.

The topic is quite interesting, because English passive voice has several possibilities of translation result from the source language (English) into the target language (Indonesian). In this research, the writer chooses the novel "Kristan Higgins' Waiting on You" and its translated version "Nina Andiana's Penantian Terpanjang", as a source of the data. I try to analyze the translation of English passive voice of that novel. The reason I choose this novel as the source of the data for my research because this novel consists of many "Passive voices". The writer is interested in doing this research because I can find out the translation of English passive voice into Indonesian.

\section{Method}

The writer uses qualitative method. According to Gay (1996:208), qualitative research is the collection and analysis of extensive narrative data in order to gain insights into a situation of interest not possible using other types of research. This approach is led to the background and the individuals themselves holistically. Therefore, this approach does not permit isolation of individual or organization into variable, but individual or organization must be included into one complete package. The writer uses the novel "Kristan Higgins' Waiting on You" and its translated "Nina Andiana's Penantian Terpanjang" as the source of the data. I use sheets of paper for taking notes about the translation of "English Passive Voice into Indonesian." The data collection procedures used by the writer are: reading the whole content of the novel, identifying passive voice in English version novel, identifying the translations of English passive voice in Indonesian version novel, and the highlighted data are put side by side into a list.

\section{Findings and Discussion}

Table 1: Translation Using Prefix $d i$ -

\begin{tabular}{|c|l|l|}
\hline No & \multicolumn{1}{|c|}{ SLT } & \multicolumn{1}{|c|}{ TLT } \\
\hline 1 & $\begin{array}{l}\text { "It's time," Colleen said firmly. Granted, “Aku sungguh-sungguh," kata Colleen } \\
\text { Paulie hadn't been blessed with great } \\
\text { beauty. (p.14) }\end{array}$ & $\begin{array}{l}\text { tegas. Ya, Paulie memang tidak } \\
\text { dikaruniai keacantikan luar biasa. } \\
\text { (p.17) }\end{array}$ \\
\hline 2 & $\begin{array}{l}\text { Her face was dotted with giant freckles, } \\
\text { rather than a sprinkling of cinnamon, and } \\
\text { her pale eyes were set close together. } \\
\text { (p.29) }\end{array}$ & $\begin{array}{l}\text { Wajah adik Colleen itu dihiasi bintik- } \\
\text { bintik merah raksasa, bukannya sedikit } \\
\text { bintik kecokelatan. Dan matanya yang } \\
\text { pucat tampak terlalu berdekatan. (p.38) }\end{array}$ \\
\hline 3 & $\begin{array}{l}\text { Not 'gray." She hadn't said the word } \\
\text { gray once. The word sheet had also not } \\
\text { been mentioned. (p.31) }\end{array}$ & $\begin{array}{l}\text { Colleen jelas tidak menjawab "abu- } \\
\text { abu". Tidak sekalipun ia mengucapkan } \\
\text { kata "abu-abu". Kata spreai juga tak } \\
\text { pernah disebutkan. (40) }\end{array}$ \\
\hline 4 & $\begin{array}{l}\text { Collen was immediately elected as the } \\
\text { bearer of bad news. If anyone could say it, } \\
\text { it was Colleen. (P.36) }\end{array}$ & $\begin{array}{l}\text { Dengan segera Colleen dipilih sebagai } \\
\text { pembawa kabar buruk. Kalau ada }\end{array}$ \\
\hline
\end{tabular}




\begin{tabular}{|c|c|c|}
\hline & & $\begin{array}{l}\text { seseorang yang bisa menyampaikan } \\
\text { kabar buruk, itu pastilah Colleen. (p.47) }\end{array}$ \\
\hline 5 & $\begin{array}{l}\text { Just what that was, Colleen wasn't sure, } \\
\text { but she was flattered to be included. } \\
\text { (p.48) }\end{array}$ & $\begin{array}{l}\text { Tetapi apa yang dimaksud dengan } \\
\text { semua itu, Colleen tidak yakin, tapi ia } \\
\text { tersanjung karena diikursertakan } \\
\text { dalam kelompok tersebut. (p.63) }\end{array}$ \\
\hline 6 & $\begin{array}{l}\text { The week before prom was consumed } \\
\text { with talk of dresses, hairstyles, shoes and } \\
\text { how to stop a guy from going too far. } \\
\text { (p.55-56) }\end{array}$ & $\begin{array}{l}\text { Minggu sebelum prom dipenuhi } \\
\text { obrolan tentang gaun, gaya rambut, } \\
\text { sepatu, dan bagaimana cara } \\
\text { menghentikan cowok yang ingin } \\
\text { berhubungan terlalu jauh. (74) }\end{array}$ \\
\hline 7 & $\begin{array}{l}\text { Granted, being protected wasn't really } \\
\text { Colleen's thing, as she'd never needed It } \\
\text { before, but damn. (p.69) }\end{array}$ & $\begin{array}{l}\text { Sungguh, Colleen tidak terlalu suka } \\
\text { dilindungi, karena sebelumnya ia } \\
\text { memang belum pernah } \\
\text { memerlukannya, tapi wow. (p.91) }\end{array}$ \\
\hline 8 & $\begin{array}{l}\text { Then, after seven months, word came that } \\
\text { Dan was being transferred. (p.106) }\end{array}$ & $\begin{array}{l}\text { Lalu, setelah tujuh bulan, datang kabar } \\
\text { bahwa Dan dipindahkan. (p.140) }\end{array}$ \\
\hline 9 & $\begin{array}{l}\text { Dad was being moved on Monday. It was } \\
\text { already Wednesday. (p.106) }\end{array}$ & $\begin{array}{l}\text { Dad akan dipindahkan hari Senin. Saat } \\
\text { itu sudah hari Rabu. (140) }\end{array}$ \\
\hline 10 & $\begin{array}{l}\text { When he saw Colleen on the dock, being } \\
\text { held by that dickless wonder, he felt } \\
\text { something bigger and more powerful than } \\
\text { anything he'd felt since his father had } \\
\text { been led out of the courtroom in } \\
\text { handcuffs. (p.132) }\end{array}$ & $\begin{array}{l}\text { Waktu melihat Colleen di dermaga, } \\
\text { dipegangi oleh anak bodoh itu, ia } \\
\text { merasa lebih besar dan kuat daripada } \\
\text { yang pernah dirasakannya sejak ayanya } \\
\text { dibawa keluar dari ruang sidang dengan } \\
\text { tangan terborgol. (p.173) }\end{array}$ \\
\hline 11 & $\begin{array}{l}\text { When he saw Colleen on the dock, being } \\
\text { held by that dickless wonder, he felt } \\
\text { something bigger and more powerful than } \\
\text { anything he'd felt since his father had } \\
\text { been led out of the courtroom in } \\
\text { handcuffs. (132) }\end{array}$ & $\begin{array}{l}\text { Waktu melihat Colleen di dermaga, } \\
\text { dipegangi oleh anak bodoh itu, ia } \\
\text { merasa lebih besar dan kuat daripada } \\
\text { yang pernah dirasakannya sejak ayanya } \\
\text { dibawa keluar dari ruang sidang } \\
\text { dengan tangan terborgol. (p.173) }\end{array}$ \\
\hline 12 & $\begin{array}{l}\text { He felt as if he'd been sliced open with a } \\
\text { blade so sharp he was a little confused as } \\
\text { to why his guts were spilling onto the } \\
\text { street. (p.150) }\end{array}$ & $\begin{array}{l}\text { Rasanya tubuhya dibelah dengan pisau } \\
\text { yang sangat tajam sehingga ia sedikit } \\
\text { bingung kenapa isis perutnya kini } \\
\text { seperti tumpah ke jalanan. (198) }\end{array}$ \\
\hline 13 & $\begin{array}{l}\text { The man continued to stare "I don't want } \\
\text { to be castrated," he said, raising a tousled } \\
\text { eyebrow. (p.161) }\end{array}$ & $\begin{array}{l}\text { Pria itu terus menatap. "Aku tidak mau } \\
\text { dikebiri," katanya sambil menaikkan } \\
\text { alis yang berantakan. (p.212) }\end{array}$ \\
\hline 14 & $\begin{array}{l}\text { In other words, accept or be discarded. } \\
\text { (p.182) }\end{array}$ & $\begin{array}{l}\text { Dengan kata lain, terima ini atau kau } \\
\text { dibuang. (p. } 240 \text { ) }\end{array}$ \\
\hline 15 & $\begin{array}{l}\text { Cried so hard it hurt, and she understood } \\
\text { why they called it heartbreak, because it } \\
\text { really did seem as if she was being ripped } \\
\text { in half from the inside out. (p.191) }\end{array}$ & $\begin{array}{l}\text { Ia menangis begitu keras sampai } \\
\text { rasanya menyakitkan, dan ia paham } \\
\text { mengapa ini disebut patah hati, karena } \\
\text { rasanya hatinya memang dibelah } \\
\text { menjadi dua. (p.251) }\end{array}$ \\
\hline 16 & It was nice to be needed. (p.216) & $\begin{array}{l}\text { Dibutuhkan memang } \\
\text { menyenangkan. (283) }\end{array}$ \\
\hline
\end{tabular}




\begin{tabular}{|c|c|c|}
\hline 17 & $\begin{array}{l}\text { When Frank Forbes was, had first } \\
\text { summoned him after learning that Lucas } \\
\text { had impregnated his angel, it was fair to } \\
\text { say that Lucas expected to be thrown } \\
\text { from the fifty-fifth story. (p.216) }\end{array}$ & $\begin{array}{l}\text { Ketika Frank Forbes pertama kali } \\
\text { memanggil Lucas setelah tahu ia } \\
\text { menghamili anak perempuan } \\
\text { kesayangannya, cukup logis jika Lucas } \\
\text { mengira ia akan dilempar keluar dari } \\
\text { lantai 55. (p.283) }\end{array}$ \\
\hline 18 & $\begin{array}{l}\text { If you hurt, mistreat or cheat on my } \\
\text { daughter, I promise you your body will } \\
\text { never be found. (p.127) }\end{array}$ & $\begin{array}{l}285 \text { Jika kau sampai menyakiti; } \\
\text { memperlakukan dengan tidak baik, atau } \\
\text { berselingkuh dari putriku, aku janji } \\
\text { mayatmu tidak akan pernah } \\
\text { ditemukan. }\end{array}$ \\
\hline 19 & $\begin{array}{l}\text { Lucas went to work, worked hard, kept his } \\
\text { head down and did what he was told. } \\
(218-219)\end{array}$ & $\begin{array}{l}\text { Lucas bererja, dengan keras, tidak } \\
\text { berubah menjadi sombong dan selalu } \\
\text { menuruti apa pun yang diperintahkan } \\
\text { padanya. (p. } 287 \text { ) }\end{array}$ \\
\hline 20 & $\begin{array}{l}\text { Colleen looked away. Paulie had been } \\
\text { instructed to high-five Bryce every time } \\
\text { he got a hit (he was really good), so } \\
\text { Colleen had to keep an aye on that. } \\
\text { (p.264) }\end{array}$ & $\begin{array}{l}\text { Colleen memalingkan wajah. Paulie } \\
\text { diberi instruksi untuk tos dengan } \\
\text { Bryce setiapkali pria itu berhasil } \\
\text { memukul bola (dia benar-benar hebat), } \\
\text { jadi Colleen harus memperhatikan hal } \\
\text { itu. (p.347) }\end{array}$ \\
\hline 21 & $\begin{array}{l}\text { Lucas was in Ithaca to see the attorney, } \\
\text { who'd been recommended by an old } \\
\text { college friend. ( } 289 \text { ) }\end{array}$ & $\begin{array}{l}\text { Lucas berada di Ithaca untuk bertemu } \\
\text { dengan pengacara itu, yang } \\
\text { direkomendasikan oleh teman } \\
\text { kuliahnya. (p.380) }\end{array}$ \\
\hline 22 & alled & $\begin{array}{l}\text { Karena ya, pasukan penolong memang } \\
\text { telah dipanggil. (386) }\end{array}$ \\
\hline 23 & $\begin{array}{l}\text { To start, beet, almond and goat cheese } \\
\text { salad, followed by braised scallops in a } \\
\text { while wine reduction over celery root and } \\
\text { potato puree and topped with freshly } \\
\text { grated Romano cheese; and vanilla bean } \\
\text { crème fraiche pudding topped with fresh } \\
\text { raspberries. (p.330) }\end{array}$ & $\begin{array}{l}\text { Dimulai dengan salad bit almond, dan } \\
\text { keju kambing, diikuti simping yang } \\
\text { ditumis dengan saus kental dari anggur } \\
\text { putih dengan puree seledri dan kentang, } \\
\text { serta dihias dill segar; wortel dan } \\
\text { parsnip panggang dengan parutan keju } \\
\text { Ramona segar; dan pudding vanilla } \\
\text { crème fraiche dengan raspberry segar. } \\
\text { (p.435) }\end{array}$ \\
\hline 24 & $\begin{array}{l}\text { Lucas had thanked her for the idea ... but } \\
\text { still, it couldn't have been done without } \\
\text { perfect Ellen. (p.393) }\end{array}$ & $\begin{array}{l}\text { Lucas berterima kasih padanya atas ide } \\
\text { itu .... Tapi tetap saja, semua takkan } \\
\text { bisa dilakukan tanpa Ellen yang } \\
\text { sempurna. (p.515) }\end{array}$ \\
\hline 25 & The church was packed. (p.429) & Gereja di \\
\hline
\end{tabular}

Sentence number 1 discusses about passive voice in past perfect with prefix di-. English passive voice is hadn't been blessed, it is formed by had + to be (been) + past participle (blessed) and translated into Indonesian passive voice into dikaruniai. It is formed by using prefix $d i$ - + verb (karuniai).

Sentence number 2 discusses about passive voice in simple past with prefix $d i$ English passive voice is was dotted, it is formed by to be (was) + past participle (dotted) 
and translated into Indonesian passive voice into dihiasi. It is formed by using prefix di- + verb (hiasi).

Sentence number 3 discusses about passive voice in past perfect with prefix $\boldsymbol{d i}$-. English passive voice is had not been mentioned, it is formed by had + to be (been) + past participle (mentioned) and translated into Indonesian passive voice into disebutkan. It is formed by using prefix di- + verb (sebutkan).

Sentenc number 4 discusses about passive voice in simple past with prefix di-. English passive voice is was elected, it is formed by to be (was) + past participle (elected) and translated into Indonesian passive voice into dpilih. It is formed by using prefix $\boldsymbol{d i}-\boldsymbol{+}$ verb (pilih).

Sentence number 5 discusses about passive voice in present infinitive with prefix $\boldsymbol{d i}$ English passive voice is to be included, it is formed by to be + past participle (included) and translated into Indonesian passive voice into dikutsertakani. It is formed by using prefix $d i-$ + verb (sertakan).

Sentence number 6 discusses about passive voice in simple past with prefix $\mathbf{d i}$-. English passive voice is was consumed, it is formed by to be (was) + past participle (consumed) and translated into Indonesian passive voice into dipenuhi. It is formed by using prefix $d i$ - + verb (penuhi).

Sentence number 7 discusses about passive voice in present participle/gerund with prefix di-. English passive voice is being protected, it is formed by being + past participle (protected) and translated into Indonesian passive voice into dilindungi. It is formed by using prefix di- + verb (lindungi).

Sentence number 8 discusses about passive voice in past continuous with prefix $\mathbf{d i}$-. English passive voice is was being transferred, it is formed by to be (was) ++ being + past participle (transferred) and translated into Indonesian passive voice into dipindahkan. It is formed by using prefix $d i-$ + verb (pindahkan).

Sentence number 9 discusses about passive voice in past continuous with prefix $\boldsymbol{d i}$-. English passive voice is was being moved, it is formed by to be (was) + being + past participle (moved) and translated into Indonesian passive voice into dipindahkan. It is formed by using prefix di- + verb (pindahkan).

Sentence number 10 discusses about passive voice in present participle/gerund with prefix di-. English passive voice is being held, it is formed by being + past participle (held) and translated into Indonesian passive voice into dipegangi. It is formed by using prefix di+ verb (dipegangi).

Sentence number 11 discusses about passive voice in past perfect with prefix di-. English passive voice is hadn't been led, it is formed by had + to be (been) + past participle (led) and translated into Indonesian passive voice into dibawa. It is formed by using prefix $d i$ - + verb (bawa).

Sentence number 12 discusses about passive voice in past perfect with prefix di-. English passive voice is hadn't been sliced, it is formed by had + to be (been) + past participle (sliced) and translated into Indonesian passive voice into dibelah. It is formed by using prefix di- + verb (belah).

Sentence number 13 discusses about passive voice in present infinitive with prefix $\mathbf{d i}$-. English passive voice is to be castrated, it is formed by to be + past participle (castratred) and translated into Indonesian passive voice into dikebiri. It is formed by using prefix di- + verb (dikebiri).

Sentence number 14 discusses about passive voice in present infinitive with prefix $\mathbf{d i}$-. English passive voice is to be discarded, it is formed by to be + past participle (discarded) 
and translated into Indonesian passive voice into dibuang. It is formed by using prefix di+ verb (dibuang).

Sentence number 15 discusses about passive voice in past continuous with prefix di-. English passive voice is was being ripped, it is formed by to be (was) + being + past participle (ripped) and translated into Indonesian passive voice into dibelah. It is formed by using prefix $d i$ - + verb (belah).

Sentence number 16 discusses about passive voice in present infinitive with prefix $\mathbf{d i}$ English passive voice is to be needed, it is formed by to be + past participle (needed) and translated into Indonesian passive voice into dibutuhkan. It is formed by using prefix di- + verb (butuhkan).

Sentence number 17 discusses about passive voice in present infinitive with prefix $\mathrm{di}$ English passive voice is to be thrown, it is formed by to be + past participle (thrown) and translated into Indonesian passive voice into dilempar. It is formed by using prefix di- + verb (lempar).

Sentence number 18 discusses about passive voice in simple future with prefix $\boldsymbol{d i}$-. English passive voice is will be found, it is formed by to be + past participle (thrown) and translated into Indonesian passive voice into akan ditemukan. It is formed by using prefix di- + verb (temukan).

Sentence number 19 discusses about passive voice in simple past with prefix $\mathbf{d i}$ English passive voice is was told, it is formed by to be (was) + past participle (told) and translated into Indonesian passive voice into diperintahkan. It is formed by using prefix di+ verb (perintahkan).

Sentence number 20 discusses about passive voice in past perfect with prefix diEnglish passive voice is had been instructed, it is formed by had + to be (been) + past participle (instructed) and translated into Indonesian passive voice into diberi instruksi. It is formed by using prefix $d i$ - + verb (beri instruksi).

Sentence number 21 discusses about passive voice in past perfect with prefix $\mathbf{d i}$ English passive voice is had been recomended, it is formed by had + to be (been) + past participle (recomended) and translated into Indonesian passive voice into diinstruksikan. It is formed by using prefix $d i$ - + verb (instruksikan).

Sentence number 22 discusses about passive voice in past perfect with prefix di-. English passive voice is had been called in, it is formed by had + to be (been) + past participle (called in) and translated into Indonesian passive voice into dipanggil. It is formed by using prefix di- + verb (panggil).

Sentence number 23 discusses about a) passive voice in passive participle with prefix di-. English passive voice is followed, and translated into Indonesian passive voice into diikuti. It is formed by using prefix $\boldsymbol{d i}$ - + verb (ikuti). b) passive voice in passive participle with prefix di-. English passive voice is braised, and translated into Indonesian passive voice into ditumis. It is formed by using prefix $\boldsymbol{d i}$ - + verb (tumis). c) passive voice in passive participle with prefix di-. English passive voice is topped, and translated into Indonesian passive voice into dihias. It is formed by using prefix di- + verb (hias).

Sentence number 24 discusses about passive voice in passive perfect conditional with prefix di-. English passive voice is couldn't have been done it is formed by modal (could) + not + have + to be (been) + past participle (done) and translated into Indonesian passive voice into tidak bisa dilakukan. It is formed by using tidak + bisa + prefix di- + verb (lakukan).

Sentence number 25 discusses about passive voice in simple past with prefix $\mathrm{di}$-. English passive voice is was packed, it is formed by to be (was) + past participle (packed) 
and translated into Indonesian passive voice into dipenuhi. It is formed by using prefix di+ verb (penuhi).

Table 2: Translation Using Prefix ter-

\begin{tabular}{|c|c|c|}
\hline No & SLT & TLT \\
\hline 1 & $\begin{array}{l}\text { Her face was dotted with giant freckles, } \\
\text { rather than a sprinkling of cinnamon, and } \\
\text { her pale eyes were set close together. } \\
\text { (p.29) }\end{array}$ & $\begin{array}{l}\text { Wajah adik Colleen itu dihiasi bintik- } \\
\text { bintik merah raksasa, bukannya sedikit } \\
\text { bintik kecokelatan. Dan matanya yang } \\
\text { pucat tampak terlalu berdekatan. } \\
\text { (p.38) }\end{array}$ \\
\hline 2 & $\begin{array}{l}\text { Just what that was, Colleen wasn't sure, } \\
\text { but she was flattered to be included. } \\
\text { (p.48) }\end{array}$ & $\begin{array}{l}\text { Tetapi apa yang dimaksud dengan } \\
\text { semua itu, Colleen tidak yakin, tapi ia } \\
\text { tersanjung karena diikursertakan } \\
\text { dalam kelompok tersebut. (p.63) }\end{array}$ \\
\hline 3 & $\begin{array}{l}\text { He was locked in from the second he } \\
\text { kissed her, something he'd been thinking } \\
\text { about doing from the moment he first saw } \\
\text { her, ... (p.132) }\end{array}$ & $\begin{array}{l}\text { Lucas seolah terkunci sejak detik } \\
\text { pertama mencium gadis itu, sesuatu } \\
\text { yang sudah ingin ia lakukan sejak } \\
\text { pertama kali melihat gadis itu, ... } \\
\text { (p.173) }\end{array}$ \\
\hline 4 & $\begin{array}{l}\text { He remembered knowing not to ask for } \\
\text { seconds because whatever was left over } \\
\text { would be tomorrow's dinner, too. He'd } \\
\text { been poor, and he's seen what a lack of } \\
\text { money had driven his father to do, and he } \\
\text { was damned if he'd bring Colleen into } \\
\text { that life. (p.148) }\end{array}$ & $\begin{array}{l}\text { Ia ingat menyadari tak bisa menambah } \\
\text { makanan karena apa pun yang tersisa } \\
\text { akan dijadikan makan malam besok. } \\
\text { Dulu ia miskin, dan ia sudah melihat } \\
\text { betapa kekurangan uang mendorong } \\
\text { ayahnya melakukan apa yang dia } \\
\text { lakukan, dan terkutuklah dirinya kalau } \\
\text { sampai membawa Colleen ke } \\
\text { kehidupan itu. (p.195) }\end{array}$ \\
\hline 5 & Colleen. That & $\begin{array}{l}\text { Ia tak boleh memikirkan Colleen. Kini } \\
\text { pikiran itu terlarang. (p.286-287) }\end{array}$ \\
\hline 6 & $\begin{array}{l}\text { She'd been hit in the head with a flicking' } \\
\text { ball. "Ouch," she said faintly. (p.268) }\end{array}$ & $\begin{array}{l}\text { Kepalanya terkena bola. "Aduh," ujar } \\
\text { Colleen pelan. (p. } 354 \text { ) }\end{array}$ \\
\hline 7 & $\begin{array}{l}\text { Until Lucas had meet Colleen, everything } \\
\text { had always been....tainted, somehow. } \\
\text { (p.318) }\end{array}$ & $\begin{array}{l}\text { Sampai Lucas bertemu Colleen, segala } \\
\text { sesuatunya terasa ... ternoda, entah } \\
\text { kenapa. (p.419) }\end{array}$ \\
\hline 8 & $\begin{array}{l}\text { He was in the Food Zone, hypnotized by } \\
\text { the smells and texture of his work. (p.328) }\end{array}$ & $\begin{array}{l}\text { Connor seolah berada di Zona } \\
\text { Makanan, terhipnotis aroma dan } \\
\text { tekstur hasil karyanya. }(\mathrm{p} .433)\end{array}$ \\
\hline
\end{tabular}

Sentence number 1 discusses about passive voice in simple past with prefix ter-. English passive voice is was flattered, it is formed by to be (was) + past participle (flattered) and translated into Indonesian passive voice into tersanjung. It is formed by using prefix ter- + verb (sanjung).

Sentence number 2 discusses about passive voice in simple past with prefix terEnglish passive voice is was locked, it is formed by to be (was) + past participle (locked) and translated into Indonesian passive voice into terkunci. It is formed by using prefix ter+ verb (kunci).

Sentence number 3 discusses about: a) passive voice in simple past with prefix ter-. English passive voice is was left over, it is formed by to be (was) + past participle (left 
over) and translated into Indonesian passive voice into tersisa. It is formed by using prefix ter- + verb (sisa). : b) passive voice in simple past with prefix ter-. English passive voice is was damned, it is formed by to be (was) + past participle (damend) and translated into Indonesian passive voice into terkutuklah. It is formed by using prefix ter- + verb (kutuklah).

Sentence number 4 discusses about passive voice in simple past with prefix ter-. English passive voice is was forbidden, it is formed by to be (was) + past participle (forbidden) and translated into Indonesian passive voice into terlarang. It is formed by using prefix ter- + verb (larang).

Sentence number 5 discusses about passive voice in past perfect with prefix terEnglish passive voice is had been hit, it is formed by had + to be (been) + past participle (hit) and translated into Indonesian passive voice into terkena. It is formed by using prefix ter- + verb (kena).

Sentence number 6 discusses about passive voice in past perfect with prefix ter-. English passive voice is had been tainted, it is formed by had + to be (been) + past participle (tainted) and translated into Indonesian passive voice into ternoda. It is formed by using prefix ter- + verb (noda).

Sentence number 7 discusses about a) passive voice in passive participle with prefix ter-. English passive voice is hypnotized, and translated into Indonesian passive voice into terhipnotis. It is formed by using prefix ter- + verb (hipnotis).

Table 3: Translation Using Prefix me-

\begin{tabular}{|c|l|l|}
\hline No & \multicolumn{1}{|c|}{ SLT } & \multicolumn{1}{|c|}{ TLT } \\
\hline 1 & $\begin{array}{l}\text { Despite her own utter lack of experience, } \\
\text { Colleen was asked for advice and doled it } \\
\text { out, sounding quite expert to her own ears. } \\
\text { (p.56) }\end{array}$ & $\begin{array}{l}\text { Meskipun Colleen sendiri tidak } \\
\text { berpengalaman, banyak temannya } \\
\text { meminta saran, jawabannya memang } \\
\text { kedengaran seperti ahli, bahkan bagi } \\
\text { telinganya sendiri. (p.74) }\end{array}$ \\
\hline 2 & $\begin{array}{l}\text { At about midnight, it was decided by half } \\
\text { the group that a visit to the lake was in } \\
\text { order; for one, it was a gorgeous May } \\
\text { night, the sky gleaming with the stars, ... } \\
\text { (p.59) }\end{array}$ & $\begin{array}{l}\text { Kira-kira tengah malam, setengah } \\
\text { anggota kelompok memutuskan } \\
\text { Malam bulan Mei, langit pasti dipenuhi } \\
\text { taburan bintang, .. (p.79) }\end{array}$ \\
\hline 3 & $\begin{array}{l}\text { 230 That being said, he could see down } \\
\text { her shirt. (p.230) }\end{array}$ & $\begin{array}{l}\text { Setelah mengatakan itu, Lucas sadar ia } \\
\text { bisa melihat ke bawah ke blus Colleen. } \\
\text { (p.303) }\end{array}$ \\
\hline 4 & $\begin{array}{l}\text { No one would ever tell Savannah that } \\
\text { she'd been handed that hit. (p.267) }\end{array}$ & $\begin{array}{l}\text { Tak seorang pun akan memberitahu } \\
\text { Savannah bahwa Colleen sengaja } \\
\text { melepaskan bola itu untuknya. (p.353) }\end{array}$ \\
\hline
\end{tabular}

Sentence number 1 discusses about passive voice in simple past with prefix $\boldsymbol{m e}$-. English passive voice is was asked, it is formed by to be (was) + past participle (asked) and translated into Indonesian active voice into meminta. It is formed by using prefix $\boldsymbol{m e}$ + verb (minta).

Sentence number 2 discusses about passive voice in simple past with prefix $\boldsymbol{m e}$ English passive voice is was decided, it is formed by to be (was) + past participle (decided) and translated into Indonesian active voice into memutuskan. It is formed by using prefix me- + verb (mutuskan).

Sentence number 3 discusses about passive voice in present participle/gerund with prefix $\boldsymbol{m e}$-. English passive voice is being said, it is formed by being + past participle 
(said) and translated into Indonesian passive voice into mengatakan. It is formed by using prefix me- + verb (katakan).

Sentence number 4 discusses about passive voice in past perfect with prefix $\boldsymbol{m e}$-. English passive voice is had been handed, it is formed by had + to be (been) + past participle (handed) and translated into Indonesian active voice into melepaskan. It is formed by using prefix me- + verb (lepaskan).

Table 4: Translation Using Prefix men-

\begin{tabular}{|c|l|l|}
\hline No & \multicolumn{1}{|c|}{ SLT } & \multicolumn{1}{|c|}{ TLT } \\
\hline 1 & $\begin{array}{l}\text { He worked harder and longer than his } \\
\text { coworkers, hoping to show he wasn't just } \\
\text { some schmuck who was being promoted } \\
\text { because of who he was. (p.220) }\end{array}$ & $\begin{array}{l}\text { Ia bekerja lebih keras dan lebih lama } \\
\text { daripada rekan-rekannya, berharap bisa } \\
\text { menunjukkan ia bukan sekedar orang } \\
\text { berengksek yang mendapat promosi } \\
\text { karena menikahi putri sang bos. (p.289) }\end{array}$ \\
\hline 2 & $\begin{array}{l}\text { As he was promoted, moving up through } \\
\text { the ranks from construction worker to } \\
\text { foreman to project manager. (p.220) }\end{array}$ & $\begin{array}{l}\text { Dan Lucas memang mendapat } \\
\text { promosi, menaiki tangga karier dari } \\
\text { pekerja konstruksi menjadi mandor, } \\
\text { kemudian menjadi manajer proyek. } \\
\text { (p.289) }\end{array}$ \\
\hline 3 & $\begin{array}{l}\text { From somewhere not too far away, an owl } \\
\text { called and was answered. (345) }\end{array}$ & $\begin{array}{l}\text { Dari suatu tempat yang tak terlalu jauh, } \\
\text { burung hantu memanggil-manggil dan } \\
\text { mendapatkan jawaban. (455) }\end{array}$ \\
\hline
\end{tabular}

Sentence number 1 discusses about passive voice in past continuous with prefix men-. English passive voice is was being promoted, it is formed by to be (was) + being + past participle (promoted) and translated into Indonesian active voice into mendapat promosi. It is formed by using prefix men- + verb (dapat) + promosi.

Sentence number 2 discusses about passive voice in simple past with prefix men-. English passive voice is was promoted, it is formed by to be (was) + past participle (promoted) and translated into Indonesian active voice into mendapat promosi. It is formed by using prefix men- + verb (dapat) + promosi.

Sentence number 3 discusses about passive voice in simple past with prefix men-. English passive voice is was answered, it is formed by to be (was) + past participle (answered) and translated into Indonesian active voice into mendapatkan jawaban. It is formed by using prefix men- + verb (dapatkan) + jawaban.

\section{Table 5: Translation Using Prefix ber-}

\begin{tabular}{|c|l|l|}
\hline No & \multicolumn{1}{|c|}{ SLT } & \multicolumn{1}{|c|}{ TLT } \\
\hline 1 & $\begin{array}{l}\text { Faith and Jeremy were snuggled on the } \\
\text { couch, the golden couple, prom king and } \\
\text { queen, of course, as if anyone else had a } \\
\text { chance. (p.58) }\end{array}$ & $\begin{array}{l}\text { Faith dan Jeremy berpelukan di sofa, } \\
\text { si pasangan emas, raja dan ratu prom, } \\
\text { tentu saja, seolah pasangan lain punya } \\
\text { kesempatan saja. (p.77) }\end{array}$ \\
\hline 2 & $\begin{array}{l}\text { An hour later, the sunroom was } \\
\text { transformed. (p.293) }\end{array}$ & $\begin{array}{l}\text { Sejam kemudian, ruang berjemur } \\
\text { sudah berubah. (p386.) }\end{array}$ \\
\hline
\end{tabular}

Sentence number 1 discusses about passive voice in simple past with prefix $\boldsymbol{b e r}$-. English passive voice is was snuggled, it is formed by to be (was) + past participle (snuggled) and translated into Indonesian active voice into berpeluklan. It is formed by using prefix ber- + verb (pelukan).

Sentence number 2 discusses about passive voice in simple past with prefix ber-. English passive voice is was transformed, it is formed by to be (was) + past participle 
(transformed) and translated into Indonesian active voice into berubah. It is formed by using prefix ber- + verb (ubah).

\section{Conclusion}

The writer finds out that English passive voice can be translated both into Indonesian passive voice and Indonesian active voice. English passive voice is translated into Indonesian passive voice by using prefixes $d i$ - and ter-, meanwhile English passive voice is translated into Indonesian active voice by using prefixes me-, men-, and ber-. In this research, the writer analyzes 8 English passive forms such as: past perfect, simple past, present infinitive, present participle/gerund, past continues, simple future, passive participle and passive perfect conditional. I find out 8 English passive voice forms which are translated into Indonesian passive voice, namely: past perfect, simple past, present infinitive, present participle/gerund, past continues, simple future, passive participle and passive perfect conditional. Meanwhile there are 4 English passive voice forms which are translated into Indonesian active voice, namely: past perfect, simple past, present participle/gerund, and past continues. The writer realizes this research is very important to those want to become a translator or to students studying translation subject. This research also can be a good reference for reader if they want to study about English passive voice. That is why, the writer hopes for other people to continue doing this research. Since the sample of this research is still very limited, the writer suggests that other research be conducted with bigger samples to produce a more convincing result.

\section{References}

Andiana, Nina. 2015. Penantian Terpanjang. Jakarta: Gramedia.

Azar, Betty Schrampher. 1992. Fundamentals of English Grammar. New York: Prentice Hall.

Baker, Mona. 1997. In Other Words: A Coursebook on Translation. London: Routledge.

Catford, J.C. 1965. A Linguistic Theory of Translation. London: Oxford University Press.

Higgins, Kristan. 2014. Waiting on You. Canada: Harlequin HQN.

Larson, Mildred L. 1984. Meaning-Based Translation. A guide to Cross-Language Equivalence. Lanham, Maryland: University Press of America.

Newmark, Peter. 1981. Approaches to Translation. Oxford: Pergamon Press.

Widyamartaya, A. 2006. Seni Menerjemahkan. Yogyakarta: Kanisius. 